\title{
ECHINOCHITON DUFOEI: A NEW SPINY ORDOVICIAN CHITON
}

\author{
JOHN POJETA, JR., ${ }^{1}$ D. J. EERNISSE, ${ }^{2}$ R. D. HOARE,$^{3}$ AND M. D. HENDERSON ${ }^{4}$ \\ ${ }^{1}$ U.S. Geological Survey, Museum of Natural History, Smithsonian Institution, Washington, DC 20560, \\ ${ }^{2}$ Department of Biological Sciences, California State University, Fullerton, California 92834, \\ ${ }^{3}$ Department of Geology, Bowling Green State University, Bowling Green, Ohio 43403, and \\ ${ }^{4}$ Burpee Museum of Natural History, Rockford, Illinois 61103
}

\begin{abstract}
Echinochiton dufoei new genus and species is described from the Ordovician age Forreston Member, Grand Detour Formation (Blackriveran) near Beloit, Wisconsin. For a variety of reasons, we regard E. dufoei as a chiton; the species is known from four articulated or partially articulated specimens, one of which has eight plates and two of which have a mucro on the tail plate. Echinochiton dufoei differs from other chitons in having large hollow spines that project from each of the known plates. In plate shape and position, E. dufoei is much like the Upper Cambrian species Matthevia variabilis Walcott, 1885, and the Lower Ordovician species Chelodes whitehousei Runnegar, Pojeta, Taylor, and Collins (1979).
\end{abstract}

\section{INTRODUCTION}

$\mathrm{F}$ EW CHITONS are know from articulated fossil specimens, this is especially the case for Paleozoic taxa (Hoare, 2000). Presumably this is because many species lived in erosional wave impacted zones where the plates are readily disarticulated after death. In fact, most of what is known about fossil chitons is based on disarticulated isolated plates and shell fragments. We have much to learn about variation in fossil Polyplacophora. Thus, the discovery of four specimens that are both articulated and preserve the impression of the body space filling as an internal mold is exceptionally fortunate.

The new chiton Echinochiton dufoei has large, laterally projecting, hollow spines and dorsally projecting scutes not previously seen in fossil or living chitons. These structures were totally unpredictable based on what is known from other chitons.

\section{DESCRIPTIVE MORPHOLOGY}

Echinochiton dufoei new genus and species has a single row of eight bilaterally symmetrical dorsal plates (Fig. 1.1, 1.2). The tail plate is pyramidal and has an off center, posterior raised mucro (Figs. 2-5). The intermediate plates are roughly equidimensional in width and length, internally they are pyramidal in shape (Fig. 6.1, 6.6), externally the plates vary in shape from subtriangular to quadrate, and they are triangular in cross section (Fig. 6.5). Depending on preservation, the anterior end of one plate can be overlapped slightly to considerably by the posterior end of the preceding plate (Fig. 2), or the plates may be erect (Fig. 6.1). The plates are numbered 1-8 beginning with the head plate; number 8 is the tail plate (Fig. 1.1, 1.2).

In lateral view, the intermediate plates have pointed apices directed posteriorly and large apical areas (Fig. 6.1). On one specimen, an intermediate plate seems to have anterior and posterior sediment fillings of two holes in it (Fig. 6.1); these are suggestive of the two holes in the plates of the Late Cambrian chiton Matthevia variabilis Walcott (Runnegar et al., 1979).

Each of the intermediate plates has right and left sedimentfilled, hollow, tapering spines attached to them laterally (Figs. $1-6,8)$. The tail plate has two posterior hollow spines (Figs. 2$5)$. The hollow interior space of the spines goes to the end of these structures, it is widest proximally and constricted distally (Figs. 3, 4, 6.3). Both the plates and the hollow spines show growth lines (Fig. 6.2, 6.4, 6.7). The head plate is known only in cross section and, at present, it is not known if it possessed hollow spines (Fig. 1.1, 1.2). Plate number two is known only in cross section (Fig. 1.1, 1.2); however, fragments of a right hollow spine of this plate are preserved on one specimen (Figs. 2, 3).

Between the lateral and tail spines and the plates there are a series of triangular, solid dorsally projecting scutes; such scutes are also present at the bases of the lateral spines (Fig. 2 ). In internal molds, these dorsally projecting scutes form a series of slots (Figs. 3, 5.2, 6.4). The scutes are at right angles to the body plates. The scutes and body plates make three dorsal rows.

\section{INTERPRETATION OF THE MORPHOLOGY}

The single row of bilaterally symmetrical plates indicates that the plates were dorsal in position. Figures 6.1, 7.1 show the internal mold of the body cavity filling below the plates. The undersides of the internal molds of the plates above the body filling show incremental growth lines (Figs. 6.7, 7.2), as do external molds of the lateral sides of the plates (Fig. 6.2).

Posterior is indicated by the mucro on the tail plate, by the sweep of the hollow lateral spines toward the tail plate and by the sweep of the plates when seen in both dorsal and lateral views (Figs. 3 and 6.1).

The megafauna occurring in the same blocks of rock as Echinochiton dufoei includes: the gastropods Helicotoma planulata Ulrich, Trochonema sp., and ?Lophospira sp.; cyrtoconic cephalopods aff. Beloitoceras sp.; the pelecypods Ctenodonta nasuta (Hall), Cyrtodonta huronensis Billings, and Tancrediopsis sp.; strophomenoid brachiopods; and bumastin trilobites. The trilobites are fragmented, the pelecypods and brachiopods are disarticulated, and the cephalopods preserve short sections of phragmocone attached to short sections of the living chamber.

The best preserved specimen (Figs. 2-4) was in the middle of a $15 \mathrm{~cm}$ thick block of sugary dolomite; the total surface area of the block was about 1,800 square cm. However, Echinochiton dufoei and the associated fauna covered a surface area of only about 225 square $\mathrm{cm}$, and there are virtually no other fossils through the thickness of the block. Thus, E. dufoei and the other fauna are a small shell accumulation washed in from elsewhere.

In spite of the evidence from the associated shells and their placement in the rock, that the fauna had been moved and redeposited before fossilization, Echinochiton dufoei plates remained articulated. This suggests that there was more than body muscles holding the plates, spines, and scutes together; all of these structures were probably embedded in a mantle girdle.

Additional features suggesting the presence of a mantle girdle are small horizontal markings at nearly right angles to the lateral ventral edges of the plates (Figs. 6.1, 6.2, 6.7, 7.2); these markings are interpreted as reflecting spicules embedded in a girdle. 

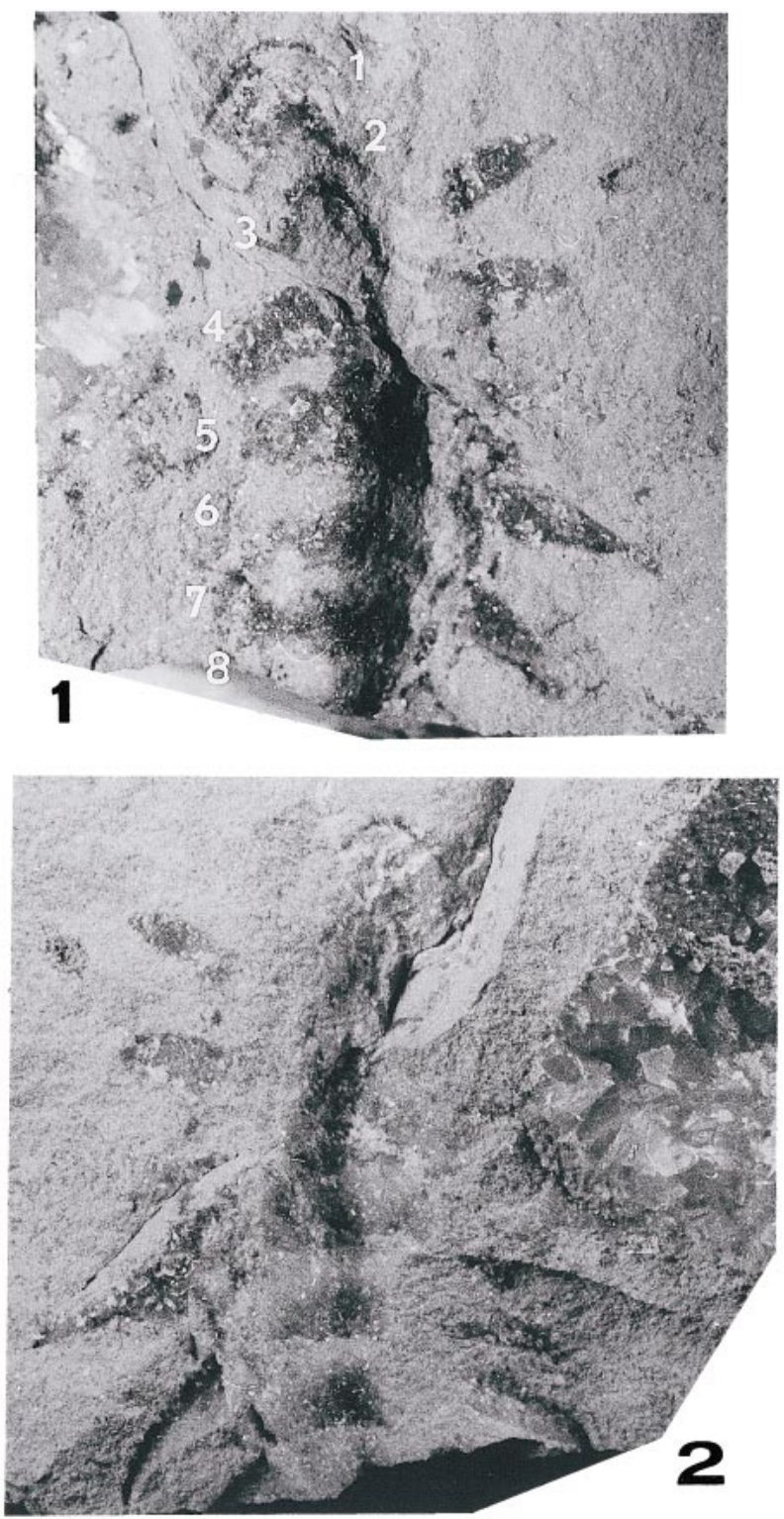

FIGURE 1-1-2, Echinochiton dufoei n. gen and sp.; paratype, 1, part (BMNH 1998.011.01) and 2, counterpart (BMNH 1998.011.02). This specimen was photographed unwhitened; it preserves eight plates numbered 1-8 from anterior to posterior, and some of the lateral hollow spines, $\times 3.4$.

The presence of scutes between the spines and the plates suggests that the spines were articulated to the plates at this point and may have been moveable.

\section{SYSTEMATIC PLACEMENT OF ECHINOCHITON DUFOEI}

For the following reasons, we consider Echinochiton dufoei to be an unusual paleoloricate polyplacophoran mollusk: 1) a specimen is known that has eight plates, which is characteristic of chitons, and the valves are bilaterally symmetrical and have growth lines; 2) the tail plate has a mucro, another characteristic of chitons; 3 ) the plates stand high with slight overlap and there is a large apical area characteristic of paleoloricates; such touching overlap of the plates as occurs may be preservational in part; 4) it is reasonable to infer that a large muscular mantle girdle was present in which the plates, scutes, and spines were embedded; and 5) it seems likely that girdle spicules were present.

In lateral profile, the shape of the plates of E. dufoei (Fig. 6.1) is much like that of the Upper Cambrian and Ordovician mattheviids described by Runnegar et al. (1979). In their reconstruction of Matthevia variabilis Walcott, Runnegar et al. (1979, p. 1375) placed the plates in the same position as they occur in Echinochiton dufoei (Fig. 6.1). The suggestion of a relationship between these two species is reinforced by a plate of E. dufoei that shows the filling of two holes in the plate (Fig. 6.1), similar holes occur in Matthevia variabilis. Hoare (2000) placed mattheviids at the base of his phylogenetic scheme of polyplacophorans.

In discussing the systematic placement of $E$. dufoei, among ourselves and with colleagues, we considered possible relationships to the Multiplacophora (Hoare and Mapes, 1995), Machaeridia (Adrain, 1992), Hercolepadida (Dzik, 1986), Thambetolepidea (Jell, 1981), Wiwaxiidae (Conway Morris, 1985), and Polyplacophora.

Hoare and Mapes (1995, p. 114) noted that multiplacophorans: 1) lack bilateral symmetry and have several types of plates that show left- and right-handedness; 2) they have small auxiliary plates associated with the intermediate plates; and 3) characteristically they have 12 plates in the skeleton. Echinochiton dufoei does not show any of these features.

Dzik (1986, p. 131), in his broadly redefined concept of Machaeridia, noted that the taxa included in the group had "... scleritized elytra arranged into longitudinal rows...." The Wiwaxiidae having about 20 such rows and the Hercolepadida having four such rows. He speculated that: ". . . it is not implausible that the chitons evolved from a machaeridian."

Adrain (1992, p. 18) regarded Dzik's definition of Machaeridia as "almost certainly polyphyletic." Adrain (p. 24) returned to the more restricted concept of Machaeridia; in defining the taxon he noted ". . . two or four longitudinal series of posteriorly imbricate sclerites. . . composed of two distinct calcite layers. ..." He regarded machaeridians (p. 18) as "a coherent group of uncertain affinity."

Whatever definition of Machaeridia is used, the species in this taxon show a great many sclerites (up to 55) in each longitudinal series (Dzik, 1986, p. 117). However, there can be far fewer sclerites; Högström and Taylor (2001) noted that Lepidocoleus sarlei Clarke has two rows each containing fourteen sclerites.

Echinochiton dufoei has a single row of 8 body plates, although it may have had as many as 10 scutes in each of two longitudinal series parallel to the body plates. In addition, the posterior plate of E. dufoei shows a distinct mucro, which is not known in machaeridians. Thus, it is unlikely that $E$. dufoei is closely related to any group included in the Machaeridia by Dzik or Adrain.

Both Jell (1981) and Conway Morris (1986) discussed a possible relationship between Thambetolepidea and Wiwaxiidae and Conway Morris (p. 526) assigned the Wiwaxiidae, with question, to the Thambetolepidea. Both taxa are covered with multiple sclerites that are unlike the plates or spines of E. dufoei, and the sclerites of Thambetolepidea have a complex internal structure very different from the hollow spines of $E$. dufoei. In addition, the sclerites of both Wiwaxiidae and Thambetolepidea show no apparent growth lines as occur in E. dufoei. Butterfield (1990) noted that the sclerites of Wiwaxiidae were not hollow, and he regarded wiwaxiids as annelids.

The valves of E. dufoei are not "saddle-like with a. . . "pinched' submedial raised region," as described by Sutton et al. (2001a) for the Silurian vermiform aplacophoran-like genus Acaenoplax (Stokstad, 2001). 


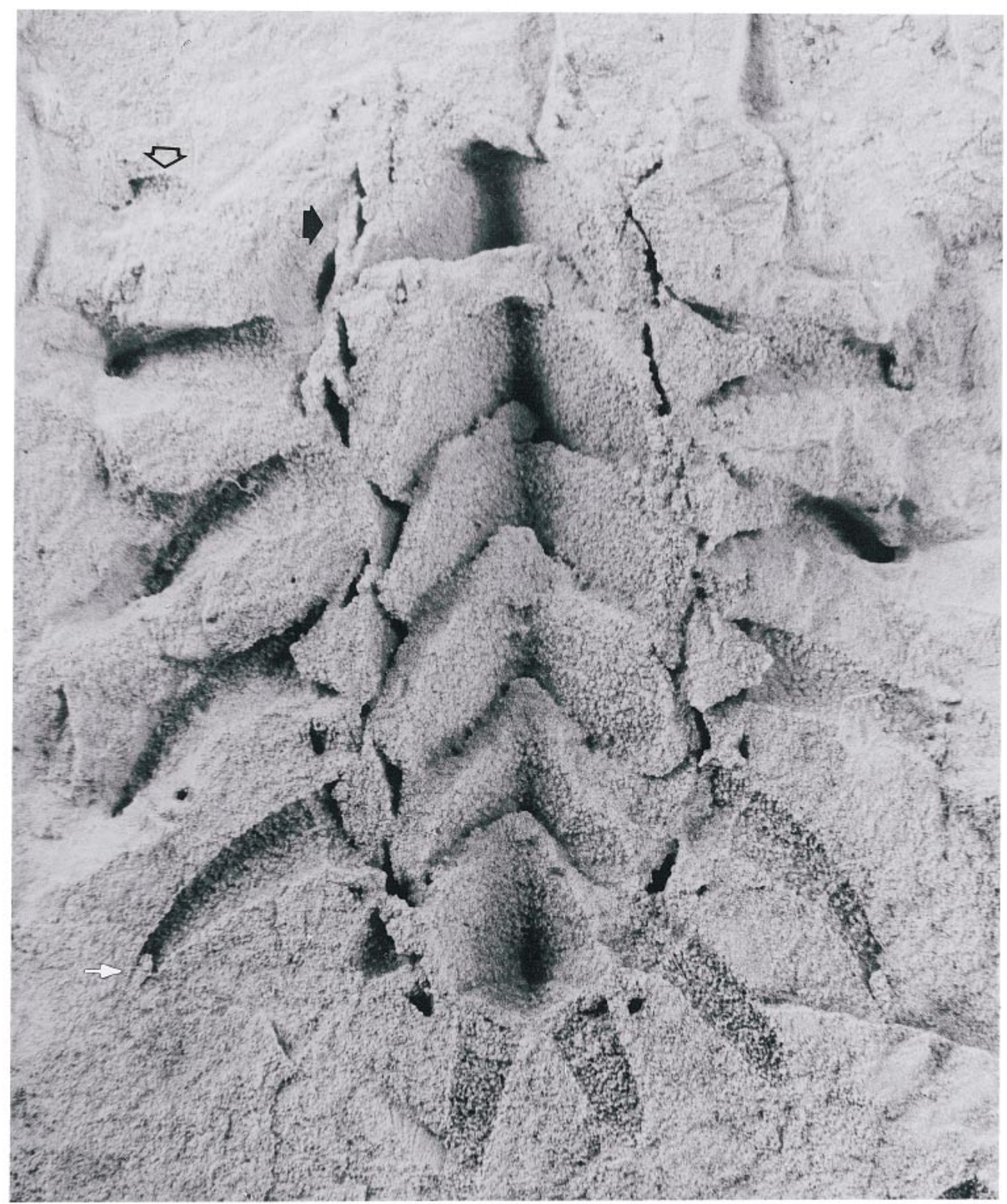

FIGURE 2-Echinochiton dufoei n. gen and sp.; holotype, part (BMNH 1996.045.01). External mold part showing six posterior plates having attached lateral and posterior hollow spines and sediment filling of spines, white arrow points to sediment filling extending to tip of spine, solid black arrow points to slots made by dorsally pointing scutes, open black arrow points to remnant of the anteriormost known spine on right side, and mucro of tail plate, $\times 4$.

Sutton et al. (2001b) described disarticulated plates from Middle Ordovician rocks of Alabama and Wales, which they assigned to the genus Eurytholia Sutton, Holmer, and Cherns. Some of these plates bear shape similarities to the plates of Echinochiton. However, their provisional reconstruction is totally different from the known articulated plates of Echinochiton.

Donovan and Paul (1985) described Dimorphoconus from Lower Ordovican rocks in England. This taxon has lateral spines superficially similar to Echinochiton. However, the entire dorsal surface of Dimorphoconus was covered with spines. The spines have a granular surface, do not show growth lines, and were probably solid.

\section{SYSTEMATIC PALEONTOLOGY}

Phylum Mollusca Cuvier, 1797

Class POLYPLACOPHORA de Blainville, 1816

Diagnosis.-Mollusks having a head, elongated body, and dorsal shell ordinarily consisting of eight articulated plates. Shell surrounded by a muscular mantle girdle that is covered by a cuticle in which spicules are embedded.

Occurrence.-Upper Cambrian to Holocene.

Order Paleoloricata Bergenhayn, 1955

Diagnosis.-Polyplacophorans having thick plates with large apical areas. Shell composed of two calcareous layers, the outer 


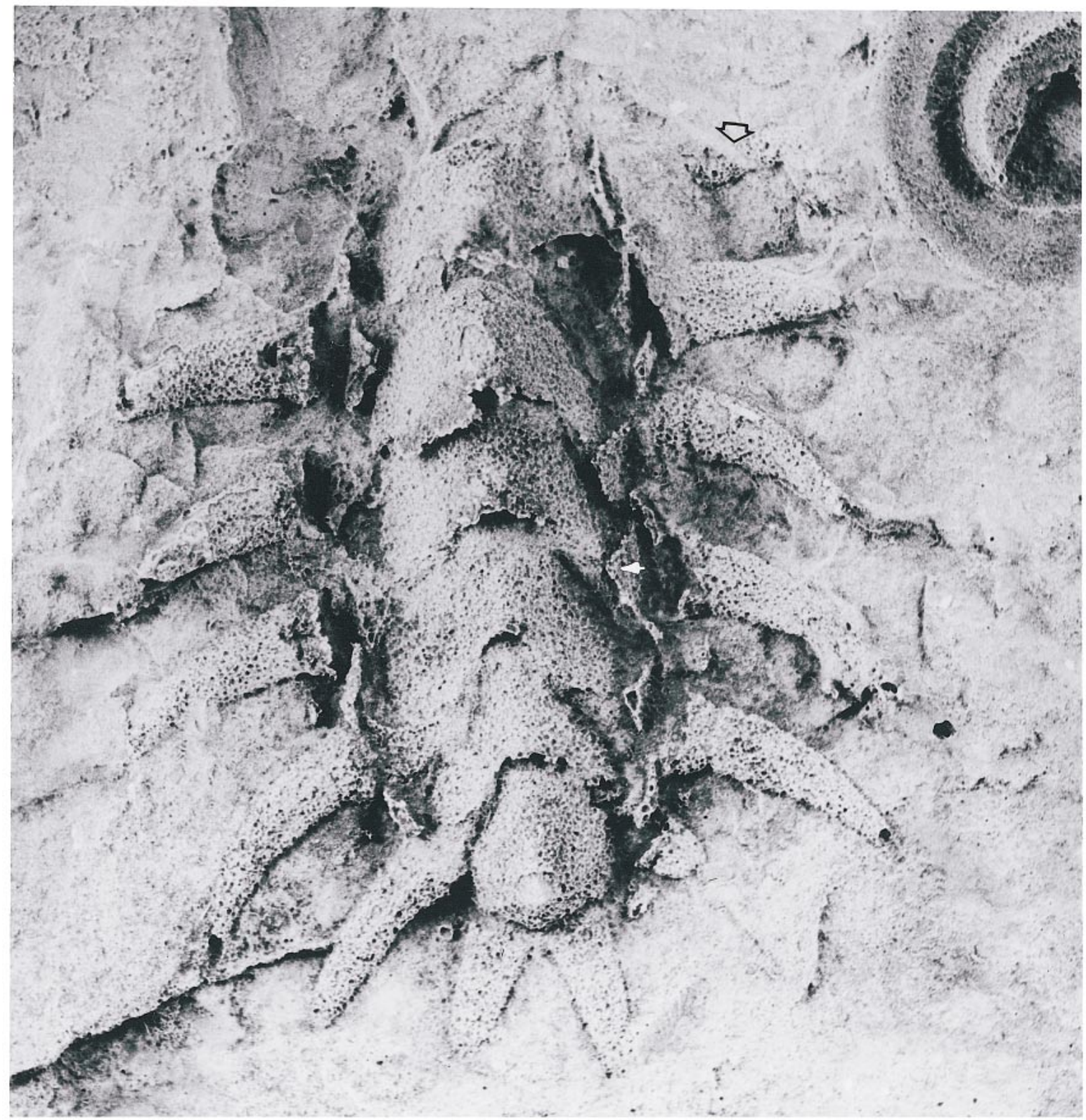

FIGURE 3-Echinochiton dufoei n. gen and sp.; Latex cast of holotype part (USNM 517482), white arrow points to a dorsally projecting scute, open black arrow points to remnant of the anteriormost known spine on the right side, $\times 4$.

tegmentum and the inner hypostracum; the articulamentum is lacking and, thus, sutural lamellae and insertion plates are absent.

Occurrence.-Upper Cambrian through Upper Cretaceous.

\section{Family ECHINOCHITONIDAE new family}

Diagnosis.-Paleoloricates having large, elongate, peripheral hollow spines attached to the plates. Length of spines more-orless equal to width of adjacent plate.

Type genus.-Echinochiton new genus is here designated the type genus of the new family Echinochitonidae.

Occurrence.-Middle Ordovician (Blackriveran).

\section{Genus ECHINOCHITON new genus}

Type species.-Echinochiton dufoei new species.

Diagnosis.-Echinochitonids having little or slightly overlapping apical areas.

Description.-Echinochitonids having eight little or slightly overlapping plates; head plate anteriorly rounded, tail plate with mucro. Intermediate plates each with one right and one left lateral hollow spine. Tail plate having right and left hollow posterior spines.

Etymology._echinos, Greek, meaning spiny; chiton, a generic name in the Polyplacophora, and, Greek, meaning tunic (Brown, 1956). 


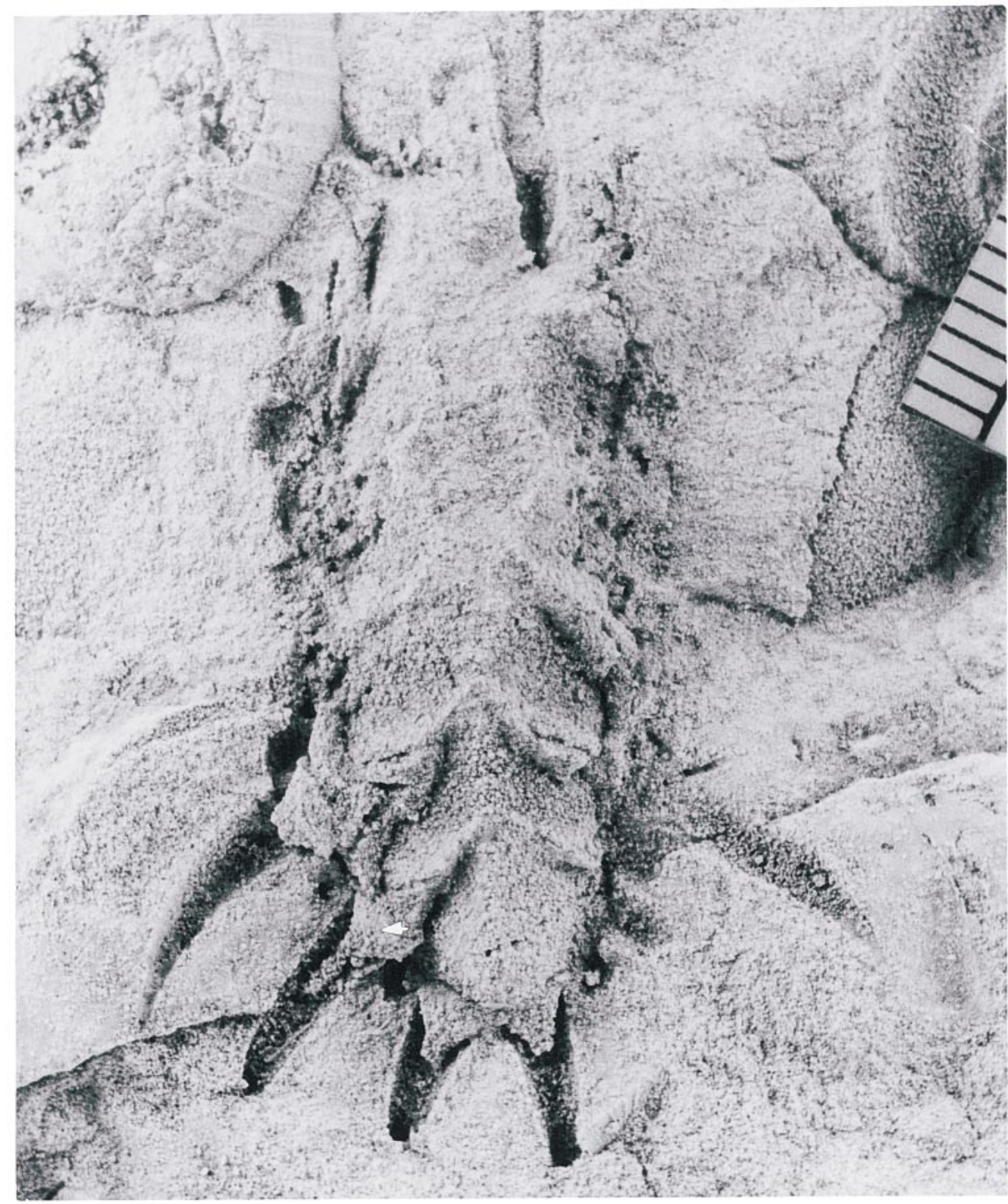

FIGURE 4-Echinochiton dufoei $\mathrm{n}$. gen and sp.; holotype counterpart (BMNH 1996.045.02), white arrow points to filling of hollow lateral spine; the filling constricts distally, $\times 4$.

Distribution.-At present, known only from the Forreston Member, Grand Detour Formation, Platteville Group, near Beloit Wisconsin (Kolata, 1975; Willman and Kolata, 1978).

\section{ECHINOCHITON DUFOEI new species} Figures 1-7

Diagnosis.—Echinochiton having intermediate plates subequal in length and width.

Description.-Echinochiton having posterior lateral spines recurved toward the tail plate; anterior lateral spines not recurved, but project normal to body length. Width and length of intermediate plates subequal. Head plate known only in cross section, tail plate rounded posteriorly, intermediate valves pyramidal and come to a dorsal point posteriorly. Known ornament consists of growth lines on the plates and lateral spines.

Etymology.-Echinochiton dufoei is named for Jimmie DuFoe of Rockton, Illinois, who discovered all known specimens and deposited them in the Burpee Museum of Natural History and the U.S. National Museum of Natural History.

Types.-The species is known from four specimens, all of which are complex internal and external molds consisting of parts and counterparts. Two of the types are deposited in the Burpee Museum of Natural History (BMNH), Rockford, Illinois, and two are in the United States National Museum of Natural History (USNM), Washington, D.C.

The holotype is a part (BMNH 1996.045.01) and counterpart 

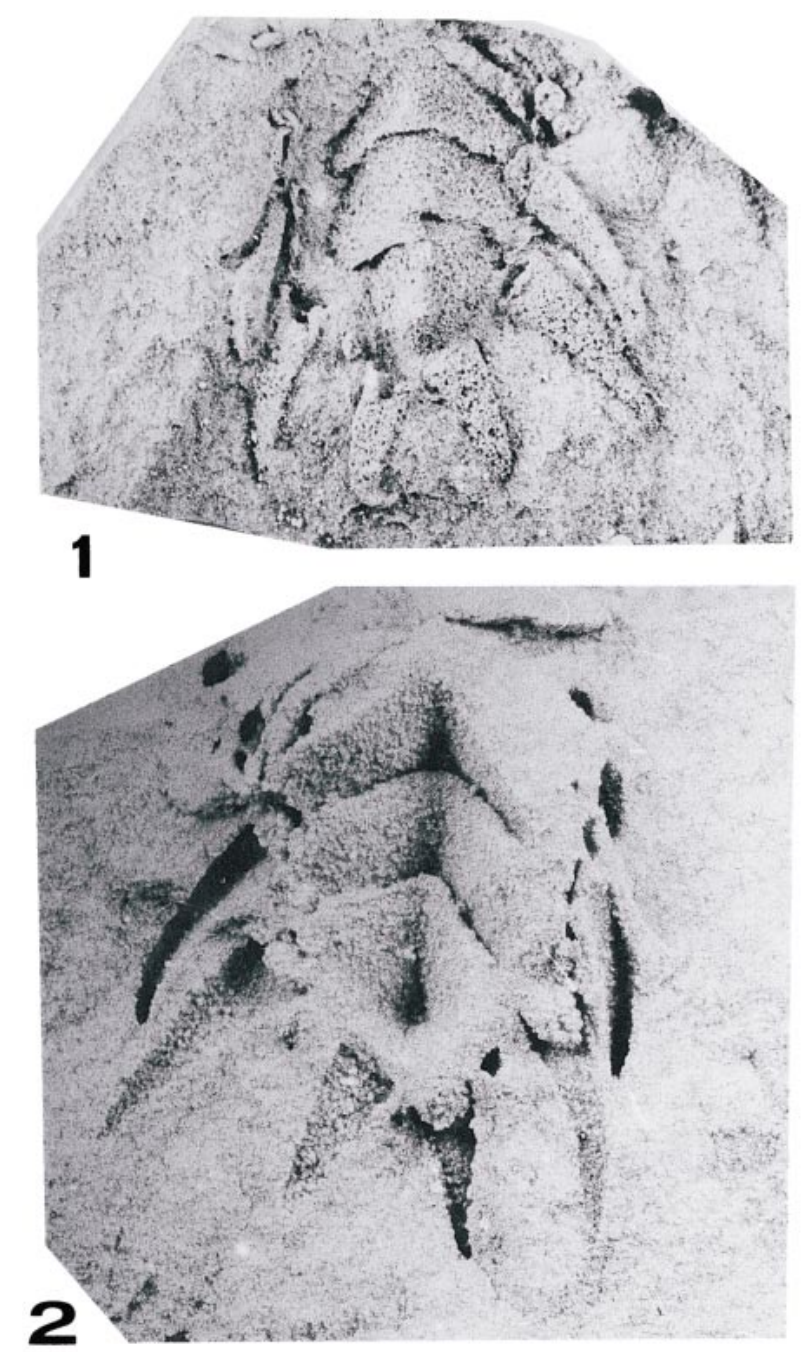

FIGURE 5-1-2, Echinochiton dufoei n. gen and sp.; paratype USNM 517480 ; 1, latex cast of three posterior plates showing lateral and posterior spines and mucro, $\times 3 ; 2$, specimen from which latex cast in Figure 5.1 was made.

(BMNH 1996.045.02) of a single individual that is shown on Figures 2-4. One paratype is a part (BMNH 1998.011.01) and counterpart (BMNH 1998.001.02) of a second individual that is shown on Figure 1. A second paratype (USNM 517480) is also a part and counterpart (Fig. 5) A third paratype (USNM 517481) is in several pieces and is the only known specimen to show growth lines on both the plates and the lateral spines, and to show the shape of the plates in lateral view (Figs. 6-7). The rock in which the specimens are preserved is a sugary calcareous dolomite.

The articulated holotype has six preserved plates with the following measurements: length $30 \mathrm{~mm}$, estimated length of eight plates $40 \mathrm{~mm}$; greatest width of an intermediate plate $11.4 \mathrm{~mm}$; greatest length of an intermediate plate $8.9 \mathrm{~mm}$; length of most completely preserved lateral spine $10.3 \mathrm{~mm}$.

The holotype part (Fig. 4) is a convex internal mold preserving portions of plates 3-8. Posteriorly, it clearly shows sediment fillings of some of the spines, which indicates that the spines were hollow.
The holotype counterpart (Figs. 2-3) is a concave mold which, after laboratory preparation, revealed the inside of six articulated plates (3-8), the sediment filling of spines on both sides, and the tail plate mucro. Between the plates and the sediment and between the plates and the spines are a series of elongate slots, which a latex replica showed to have been made by a series of dorsally projecting scutes (Fig. 2).

Paratype (BMNH 1998.001.01) preserves some of all of the eight plates, although the tail plate and the three anterior plates are incomplete. The convex paratype part (Fig. 1.1) has the plates replaced by crystalline calcite and the matrix is tightly cemented; thus, laboratory preparation was difficult and the specimen is essentially in the same condition as when it was exposed in the field. The concave paratype counterpart (Fig. 1.2) replicates the dorsal surface of the convex part; however, it is not an external mold because, some of the crystalline calcite adheres to it. The counterpart exposes parts of six spines on the left side as viewed and parts of three spines on the right side.

Paratype USNM 517480 (Fig. 5) preserves the interior of the three posterior plates (6-8) with associated spines and slots made by the vertical scutes.

Paratype USNM 517481 is a complex specimen in several pieces. When collected the specimen consisted of part (Fig. 6.1) and counterpart (Fig. 6.2). Details regarding this specimen are in the figure explanation.

Type locality.-The types are from a bed near the top of a quarry on the north side of Wisconsin State Route 81, four miles (6.4 $\mathrm{km}$ ) west of its junction with State Route 213, Rock County, Wisconsin, west of Beloit. This is the $\mathrm{SE}^{1 / 4}, \mathrm{NW}^{1} 1 / 4, \mathrm{SE}^{1} / 4$, of sec. 25, T1N, R11E (Newark Quadrangle). Access to the quarry is highly restricted, requiring written permission of the quarry owner.

Occurrence.-All known specimens are from the Forreston Member, Grand Detour Formation, Platteville Group, and are Blackriveran in age.

\section{ACKNOWLEDGMENTS}

The people with whom we discussed Echinochiton dufoei are too numerous to enumerate; we extend our grateful thanks to them all. We thank E. L. Yochelson for identifying the associated gastropods, and J. T. Dutro, Jr. for identifying the brachiopods and reviewing the manuscript; D. Erwin also reviewed the manuscript. We give special thanks to Marija Balanc and Nicole Rogalla (University of Marburg) for extensive help with the photographic illustrations. M. Parrish, Smithsonian Institution, created the marvelous reconstruction shown in Figure 8. We thank J. Adrain and P. Jell for their thoughtful reviews.

The four specimens described here represent a monumental collecting effort by J. DuFoe over a period of 10 years; we thank him for letting us study and describe them.

\section{REFERENCES}

ADRAIN, J. M. 1992. Machaeridian classification. Alcheringa, 16:15-32. BERgENHAYN, J. R. M. 1955. Die Fossilen Schwedischen Loricaten nebst einer vorlaufigen Revision des Systems der ganzen Klasse Loricata Lunds Universitets Årsskrift, n.f., Avd. 2. 51(8), Kungliga Fysiografiska Sallskapets, Handlingar, a.f. Avd2, 66(8):1-41.

Blainville, H. M. D. DE. 1816. Prodrome d'une nouvelle distribution systematique du règne animal. Société Philomatique, Paris, Nouveau Bulletin, 51-53:93-97.

BRown, R. W. 1956. Composition of Scientific words. Reese Press, Baltimore, $882 \mathrm{p}$.

ButTERFIELD, N. J. 1990. A reassessment of the enigmatic Burgess Shale fossil Wiwaxia corrugata (Matthew) and its relationship to the polychaete Canadia spinosa Walcott. Paleobiology, 16:287-303.

Conway MorRIs, S. 1985. The Middle Cambrian Metazoan Wiwaxia corrugata (Matthew) from the Burgess Shale and Ogygopsis Shale, British Columbia, Canada. Royal Society of London Philosophical Transactions (B), 307:507-586. 

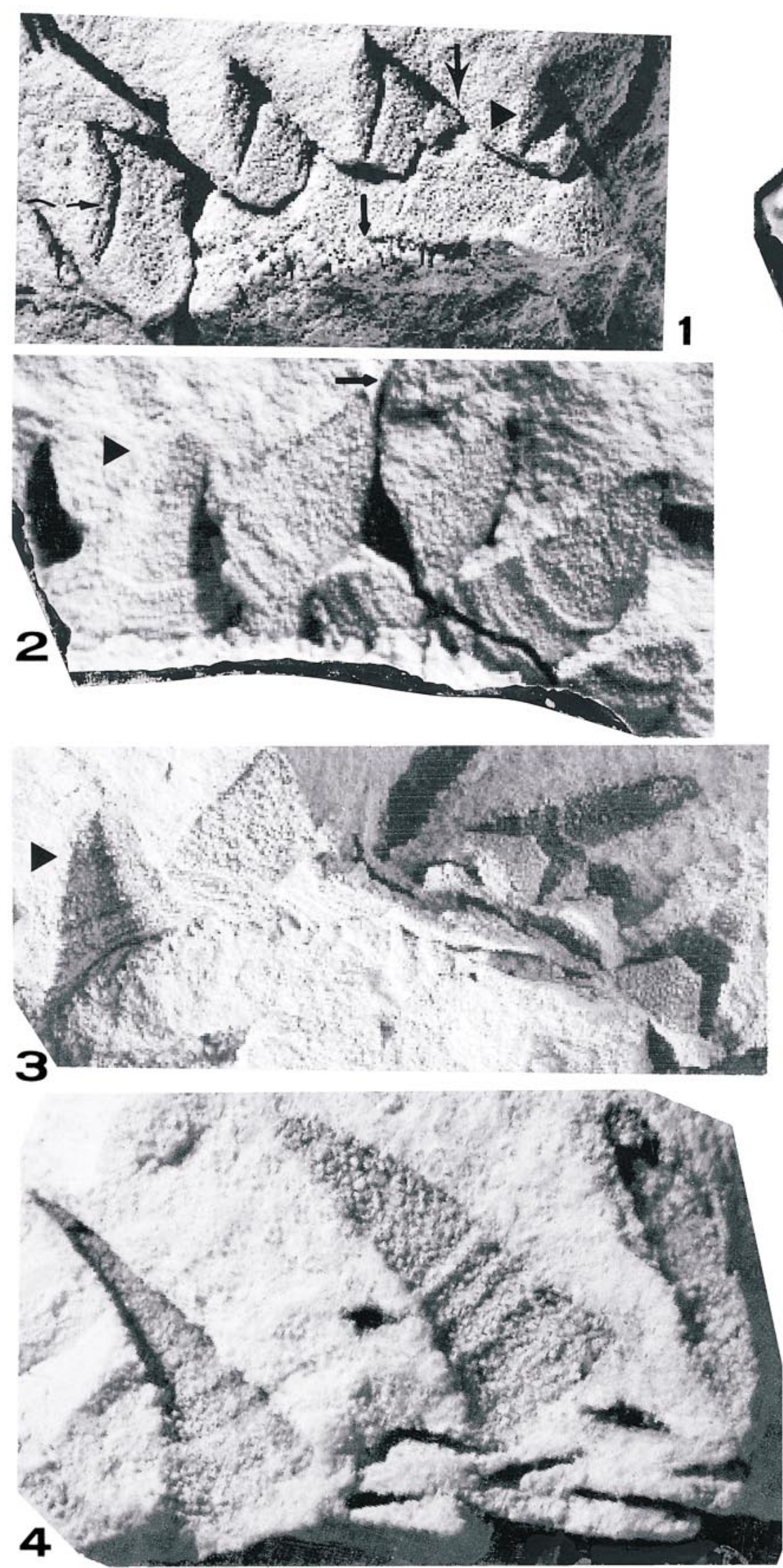
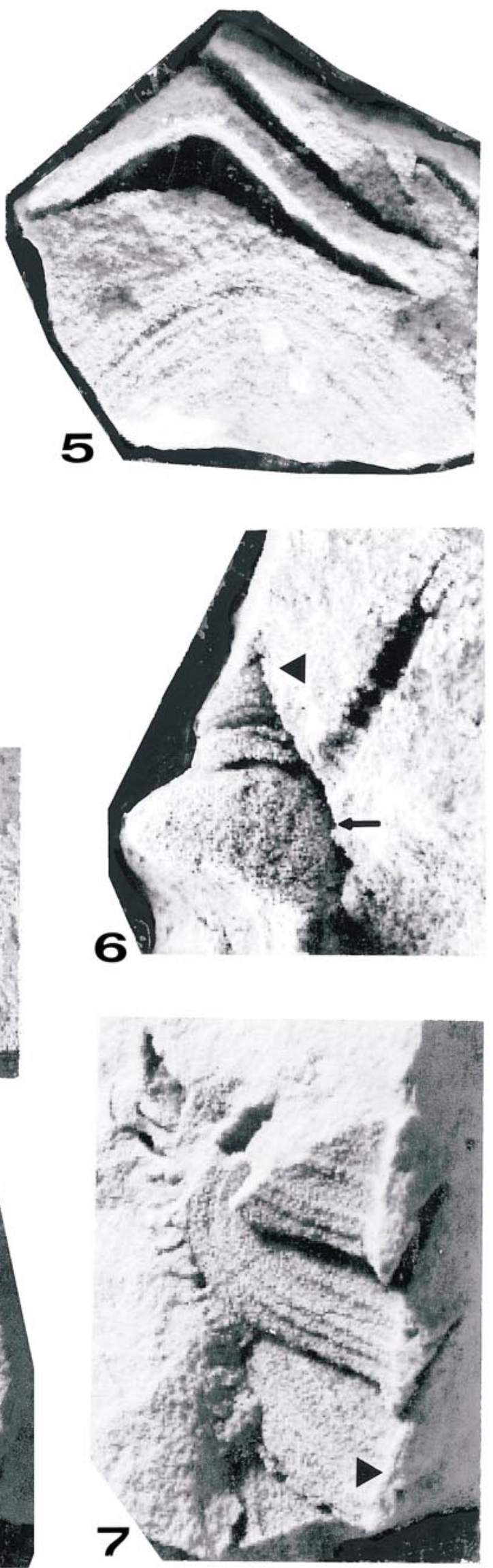
Cuvier, G. 1797. Tableau élémentaire d l'histoire naturelle des animaux. Paris, p. 1-710.

DonOvan, S. K., AND PAUL. 1985. A new possible armoured worm from the Tremadoc of Sheiton, Shropshire. Proceedings of the Geologists' Association, 96:87-91.

DzIK, J. 1986. Turrilepadida and other Machaeridia, p. 116-134. In A. Hoffman and M. H. Nitecki (eds.), Problematic Fossil Taxa. Oxford University Press, New York.

HoAre, R. D. 2000. Considerations on Paleozoic Polyplacophora including description of Plasiochiton curiosis n. gen and sp. American Malacological Bulletin, 15:131-137.

HoARE, R. D., AND R. H. Mapes. 1995. Relationships of the Devonian Strobilepis and related Pennsylvanian problematica. Acta Palaeontologica Polonica, 40:111-128.

HöGSTRÖM, A. E. S. AND W. L. TAYLOR. 2001. The machaeridian Lepidocoleus sarlei Clarke, 1896, from the Rochester Shale (Silurian) of New York State, Palaeontology, 44:113-130.

JeLL, P. A. 1982. Thambetolepis delicata gen. et sp. nov., an enigmatic fossil from the Early Cambrian of South Australia. Alcheringa, 5:8593.

KolatA, D. R. 1975. Middle Ordovician Echinoderms from northern
Illinois and southern Wisconsin. Journal of Paleontology, 49, Part II, Memoir, 7:74

RunNegar, B., J. Pojeta, JR., M. E. TAYlor, AND D. Collins. 1979. New species of the Cambrian and Ordovician chitons from Wisconsin and Queensland: evidence for the early history of polyplacophoran mollusks. Journal of Paleontology, 53:1374-1394.

Stokstad, E. 2001. New fossil may change idea of first mollusk. Science, 291:2292-2293.

Sutton, M. D., D. E. G. Briggs, David J. Siveter, and Derek J. SIVETER. 2001a. An exceptionally preserved vermiform mollusc from the Silurian of England. Nature, 410:461-463.

Sutton, M. D., L. E. Holmer, AND L. Cherns. 2001b. Small problematic phosphatic sclerites from the Ordovician of Iapetus. Journal of Paleontology, 75:1-8.

Walcott, C. D. 1885. Note on some Paleozoic pteropods. American Journal of Science, 30:17-21.

Willman, H. B., AND D. R. Kolata. 1978. The Platteville and Galena Groups in northern Illinois. Illinois State Geological Survey, Circular 502:75.

ACCEPTED 15 OCTOBER 2002

FIGURE 6-1-7, Echinochiton dufoei $\mathrm{n}$. gen and sp.; articulated paratype USNM 517481. Triangular tailless black arrow marks the same plate in all views; 1 , internal mold of part showing filling of four plates on top of internal mold filling of the body space of the animal; a piece of a fifth valve filling is marked by a wavy-tailed arrow. Straight-tailed unbarbed arrow marks impressions lateral to the body space filling, which are interpreted to be impressions of mantle girdle spicules. Straight-tailed barbed arrow points to a two-part filling of a plate, $\times 3.5 ; 2$, external mold counterpart showing impressions of six plates. The posterior five plates show growth lines. The incomplete anteriormost plate is the black impression to the left of the tailless triangular arrow. At the bottom of the plates are the impressions of presumed spicules. As viewed, the right side of the counterpart was removed along the break indicated by the tailed arrow to produce the view in Figure $6.3, \times 4 ; 3$, counterpart, the right side of the photograph showing four lateral spines; three of these show the bases of the fillings of the spines, $\times 4 ; 4$, the other side of the three of the external molds of the lateral spines showing growth lines and the slots made by the dorsally projecting scutes; 5 , triangular shape of the anterior part of the plate filling in the posteriormost complete plate in Figure 6.1; this view is in front of the pointed peak of the plate filling. Minimum thickness of the valve is seen on the right side of the specimen as viewed. Below the plate filling is an impression of the exterior of a valve showing growth lines, $\times 5 ; 6$, anterior view of rightmost plate shown in Figure 6.1; internal mold filling of body space of the shell shown below the plate (tailed arrow). Disarticulated lateral spine showing growth lines is between the two arrows, $\times 4.7 ; 7$, oblique view of the undersides of the three right plate fillings seen in Figure 6.1. These plates show growth lines and were removed from the internal mold filling of the body space of the shell, $\times 4$. 

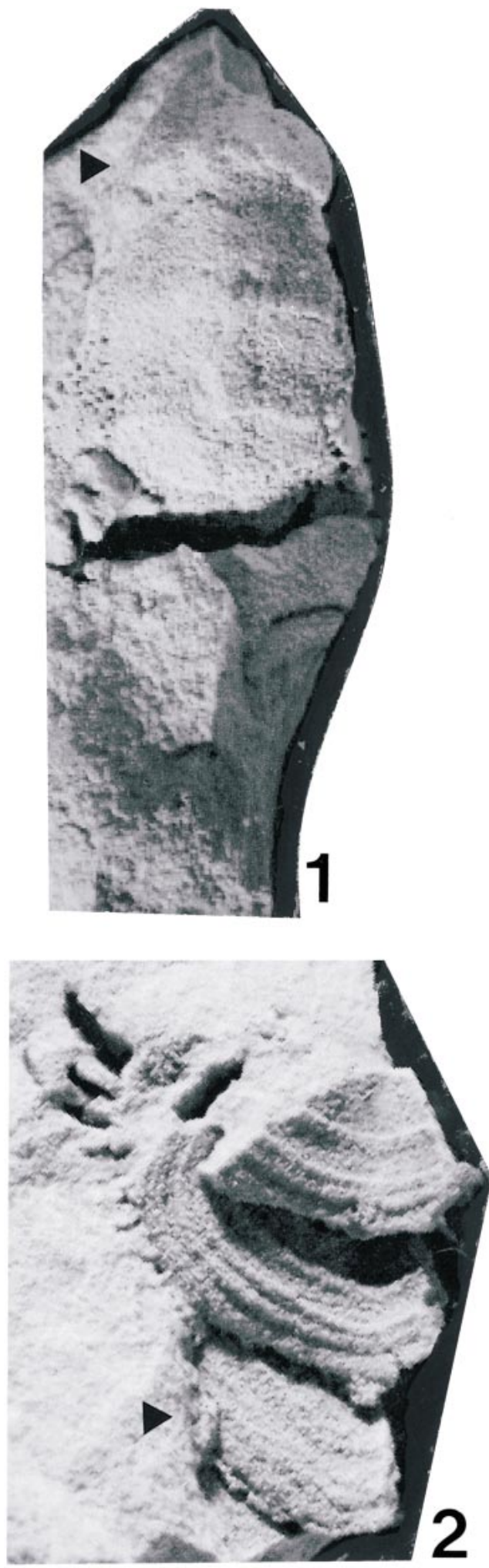

FIGURE 7-1-2, Echinochiton dufoei $\mathrm{n}$. gen and sp.; articulated paratype USNM 517481, same specimen as shown in Figure 6. 1, dorsal view of shell body space internal mold filling showing impressions of five plates, $\times 3.5 ; 2$, flat view of the undersides of the three plates shown in Figure 6.7; as viewed, the left side shows impressions of presumed mantle margin spicules, $\times 4$.

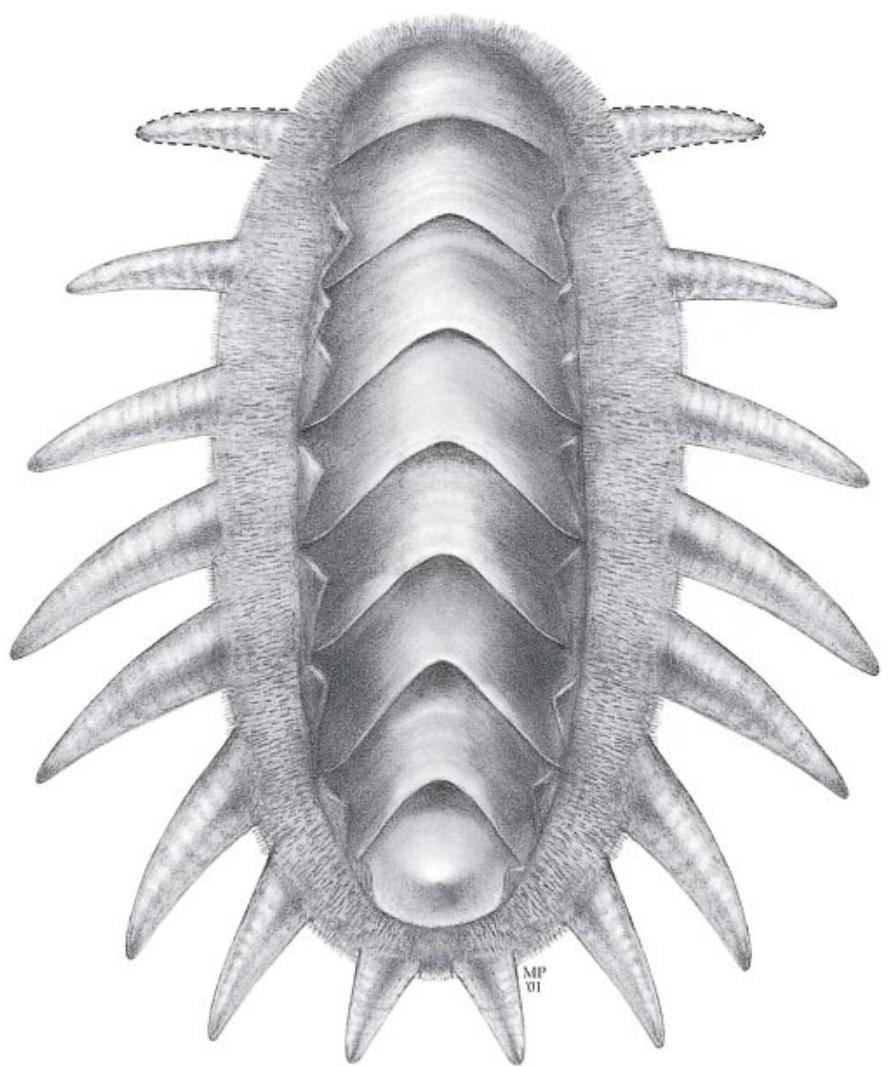

FIGURE 8-Reconstruction of dorsal surface of Echinochiton dufoei n. gen and sp. Anterior end is up. Anteriormost plate is incompletely known and shown with stylized spines; however, we reckon that additional specimens will show spines to be present. The known specimens clearly show growth lines on the lateral spines. However, the course of the growth lines on the plates is not well known, thus they are shown vaguely; no other external texture or ornament on the plates is known at present, about $\times 2.5$. 